\title{
Development Rates of Regions with GI Certification Social Development in Regions with GI
}

\author{
Alan Malacarne \\ Universidade Federal de Sergipe - UFS \\ Postgraduate Program in Intellectual Property Science - PPGPI \\ Human Cognitive Knowledge Research Laboratory - LADEC \\ Degree in Physical Education - UNESC \\ Liaria Nunes da Silva \\ Universidade Federal de Sergipe - UFS \\ Postgraduate Program in Intellectual Property Science - PPGPI \\ Human Cognitive Knowledge Research Laboratory - LADEC \\ Camila Souza Vieira \\ Universidade Federal de Sergipe - UFS \\ Postgraduate Program in Intellectual Property Science - PPGPI \\ Human Cognitive Knowledge Research Laboratory - LADEC \\ Andreia Malacarne \\ Universidade Federal de São João Del Rei - UFSJ \\ Department of Mathematics and Statistics - DEMAT \\ $\mathrm{PhD}$ in Mathematics - UFSJ \\ Post-Doctorate by the National Laboratory of Scientific Computation - LNCC \\ Robelius De-Bortoli \\ Universidade Federal de Sergipe - UFS \\ Department of Physical Education - DEF \\ Doctor of Physical Activity Science - UNILEON \\ Post-Doctorate from the University of Costa Rica
}

\begin{abstract}
The human development index and Gini Index are instruments used to measure the development of a particular region. Geographical indications are often associated with the development of certificated regions. Thus, this research raises a question about the evolution of the development indexes in regions with geographical indications of agribusiness and aims to analyze its human development. This research is classified as basic, characterized as descriptive and having a qualitativelquantitative character. After data analysis, it can be concluded that the profile of the towns is the same for the past 10 years, but with even more positive values, considering the high correlation found in the results.
\end{abstract}

Keywords: Geographical indication, Regional development, Human development index.

\section{Introduction}

The Gini Index is an instrument used to measure the degree of inequality of a particular group (Alveset al., 2017). Italian statistician Conrado Gini developed it in 1912, being used to measure inequality of income distribution, but it can be used on any type of distribution (Medeiros, 2012). This effective tool presents the income disparity of the subjects that have higher and lower income (Sartori, and Silva, 2016). Consisting of a number ranging from 0 to 1, the Gini coefficient is expressed in percentage points. When the value is equal to zero means equality, that is, if you are comparing the income of any population, everyone will receive the same salary. On the other hand, the number 1 is the antagonist of this situation, meaning that the population is in total inequality, so that a person receives all the wealth while everyone else gets nothing (Wolffenbüttel, 2004). In relation to human development, using only an instrument to measure the economic bias of a given population is insufficient to measure the improvement of their quality of life, because it must take into account social political and cultural factors (Pires et al., 2015). 
The human development index (HDI), besides assessing the economic aspects, it considers the quality of life of a population as factor of relevance (Santos et al., 2017). Three development characteristics are compared in the calculations of the HDI: longevity, education and income, thus, you can measure the degree of growth of regions, cities and countries (Oliveira et al., 2015). The inventors of the HDI were MahbubulHaq and Amartya Sen. They determined a range that goes from 0 to 1 to measure the development of a given population, according to the calculations made in this type of index, the closer to 1, the greater the degree of development of the region or country searched (da Cunha and Ferreira, 2016).

In Brazil it was adopted the Municipal Human Development Index (IDHM) which adopts the same concepts of the global HDI (Longevity, education and income), but with a focus on Brazilian towns (Gomes et al., 2017). The benchmarking of the data from the income of the population is done by per capitaincome in the town. The income of allplus all proceeds from retirements, pensions and salaries and divided by the number of inhabitants, the data are measured by life expectancy and education data are measured by the amount of time each individual attended educational institutions, whether in supplementary courses, primary and secondary school, classes of acceleration or college graduate (Duarte and Chandra, 2016).

According to Pinto, Rocha and Pirani, (2018) in addition to the three concepts measured by the HDI, one must take into consideration the categorization between the urban and rural areas, in order to broaden the understanding of the Brazilian reality, including socio-economic aspects of these two distinct spaces. That way the importance of study of development indexes as the Gini Index and the IDHM according to urban and rural reality can be seen. Therefore, the research raises a question about the evolution of the indexes in the regions with a geographical indications (GIs) of agribusiness and aims to analyze its human development that, in addition to belonging to the rural areas, have a differentiated agricultural practice, which was subject to certification.

\section{Material and Methods}

Following the materials and the method used in this research are presented, identifying the type of survey, as the collection of data and the procedures used. On the website of the National Institute of Industrial Property (INPI), the data of granted GIs certification was accessed, collecting the names of the associations'host towns with agribusiness GIs. Later, the GIs that protected the alcoholic drinks were selected, because they are the ones that have higher number of certificates within the agribusiness.

\subsection{Search Type}

About its nature, this research is classified as basic, as it is geared towards generating knowledge without practical application, in order to solve problems (Da Silva andMenezes, 2005). In accordance with its objectives, the research is characterized as descriptive, because it establishes connections between variables and facts (Cervo et al., 2007). Regarding theaddressing of the issue, this is a qualitative/quantitative character research, as it uses resources and statistical techniques as well as has an interpretative addressof the reality of data (Marconi andLakatos, 2017).

\subsection{Data collection and procedures}

We conducted a bibliographic survey on public domain and documentary search on the website of the Oswaldo Cruz Foundation (Fiocruz). The database of the United Nations Development Programme (UNDP) was accessed where it was possible to collect the historical Series of IDHM and selected indicators. It was collected data from the 2000 and 2010 Censusof townswithGI of agribusiness. The results are presented in a descriptive form.

\subsection{Statistical analysis}

The data were compared with each other through the temporal analysis of the rates of the 10-year censuses. The data related General IDHM, education, general longevity and income, in addition to the Gini Index of cities of Abaíra, Bento Gonçalves, Farroupilha, Flores da Cunha, Monte Belo do Sul, Parati, Salinas and Urussanga, composing a graph of each category. Soon after, it was applied the Pearson correlation coefficient by comparing the general data of each chart generated.

\section{Results and Discussion}

The results were compared and grouped the data from the Human development indexes of Education category, of the GIshost towns of Brazil's known alcoholic drinks. In Figure 1 is the representation of the growth of education ratesbetween the years 2000 to 2010. It is observed that the town of Abaíra in Bahia has the lowest rates both in the year 2000 as the year of 2010. It is also a noticeable trend of high rates in the towns of Rio Grande do Sul State, highlighted by Bento Gonçalves and Farroupilha. 
Figure 1. Municipal Human Development Index (IDHM) of host towns of the GIs of alcoholic drinks for the education

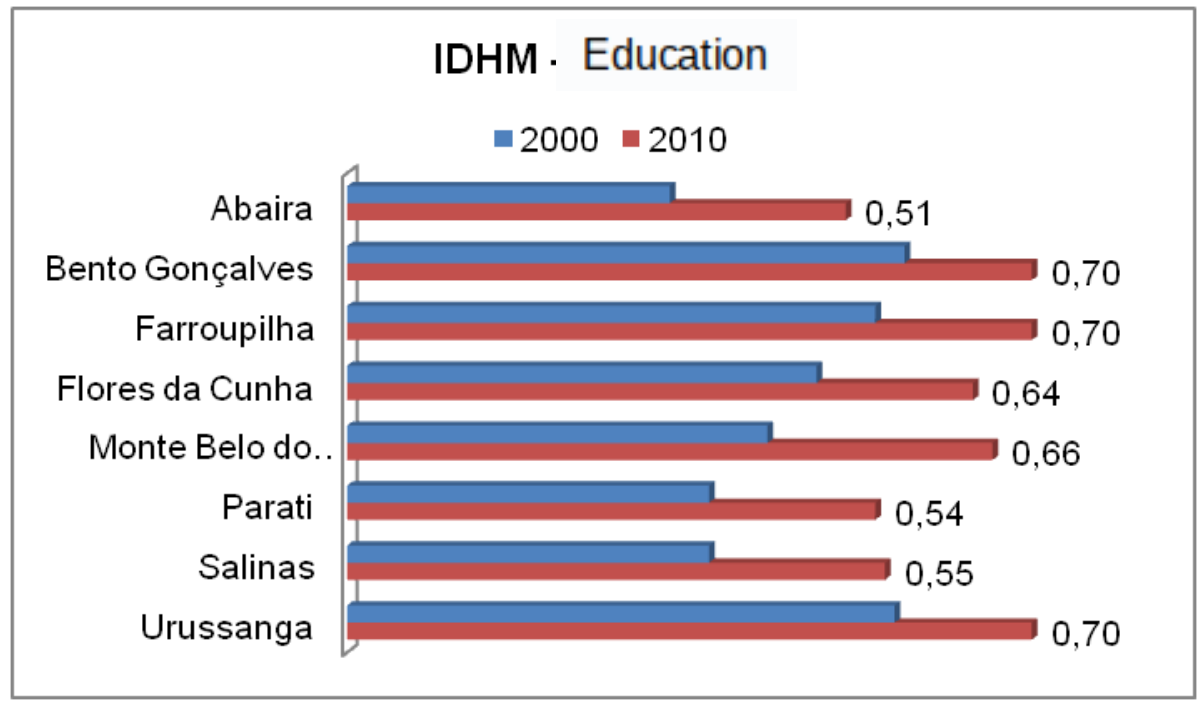

The Figure 1 shows that during a period of ten years, every host town of the GIs alcoholic drinks had a growth in education-related development indexes. According to Pegorare et al. (2016) better educational development systems increase the IDHM. An improvement in educational contents can generate more jobs in the regions, since the suitably qualified population open up more opportunities for various positions to be occupied by someone who specializes in a particular area (Mamodia and Lopes, 2016).

The towns of Abaíra, Parati and Salinas had the lowest IDHM rates in education in the year 2000, and after ten years appeared again with the lowest rates between host towns of the GIs alcoholic drinks. According to the statistical data of da Silva Martins et al. in (2017), the States of Bahia and Minas Gerais (representing the cities of Abaíra and Salinas respectively) had lower education IDHM indexes than States in southern Brazil (Rio Grande do Sul, Santa Catarina and Paraná) which can justify these low indicators of education, since there is a tendency of the towns to follow the evolution of their respective States (Mendes, 2017). The counterbalance of this thesis is the fact that the city of Parati also have low levels of education, antagonistically in relation to its home State Rio de Janeiro, which according to the research of da Silva et al. (2017) is among the best States in the education ranking, being ahead even of the Southern towns.The data were analyzed as the Municipal human development index of Longevity. The figure 2 presents the results of the cities of Abaíra, Bento Gonçalves, Farroupilha, Flores da Cunha, Monte Belo do Sul, Parati, Salinas and Urussanga. Higher values are evident in Urussanga in the State of Santa Catarina. The lowest values are again with Abaíra, despite having grown greatly in 2000 the 2010 rates, remains with a low percentage.

Figure 2. Human development index of host towns of the GIs of alcoholic drinks at longevity category

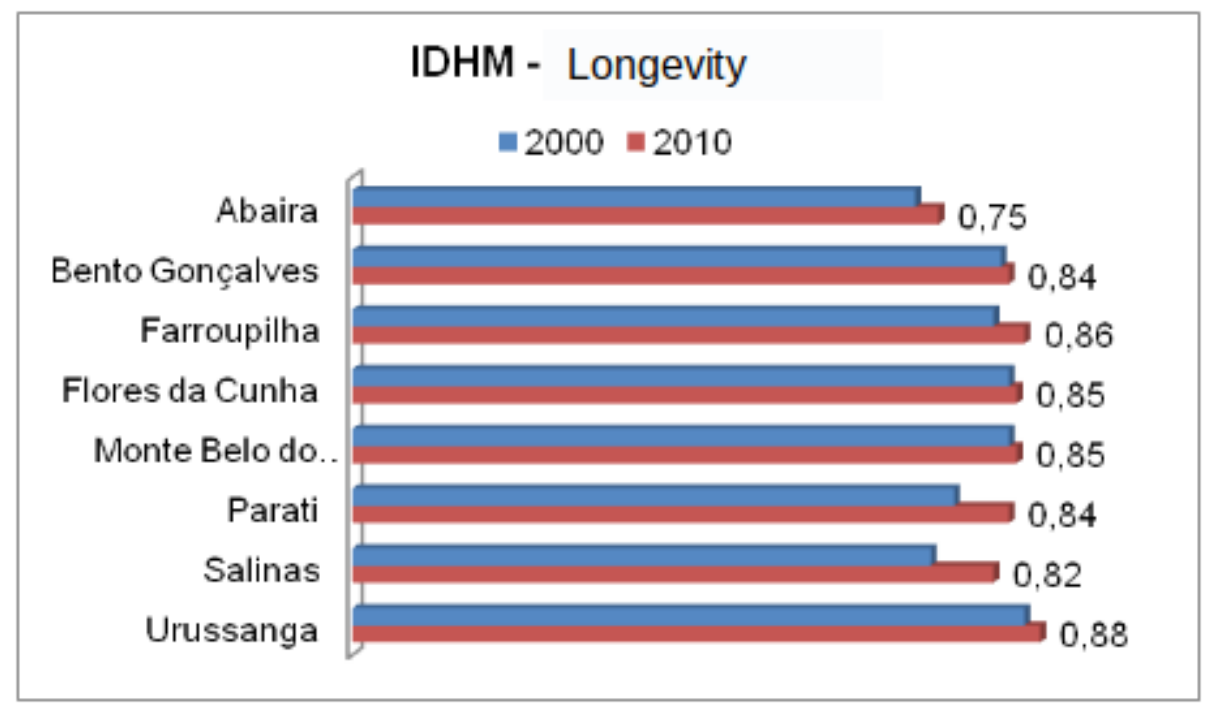


A positive aspect to be observed in Figure 2 is that the GI host towns of alcoholic drinks became more homogeneous (0.052:0.039) because statistical data show that the standard deviation is less than in 2010. Regarding the longevity of the population of the towns, there was a growth of indicators from 2000 to 2010. This increase is most noticeable in the towns of Salinas and Parati. According to da Costa and Scheffer (2017), the longevity of a given region will raise according to the increase the access to health of the resident population. One of the factors for greater longevity of the Brazilian population is the combination of lower fertility and mortality decline (Malta et al., 2008), although this factor will cause an increase of the elderly Brazilian population in the future, confirming the research ofCampos and Gonçalves (2018) that indicate that Brazil's elderly population will increase from $8.6 \%$ of seniors (2010) to $20 \%$ in 2050. To calculate the economic growth of the GI host townsof alcoholic drinks, it has been calculated the progress of Municipal human development indexes ofthe Income category. In Figure 3 it is observed that the city of Salinas in Minas Gerais presents a number well below the southern towns of the country, while Bento Gonçalves stands out with the best rates. Again, Abaíra has the lowest numbers, keeping its distance from the other towns studied.

\section{Figure 3. Human development index of host towns of the GIs of alcoholic drinks at Income category}

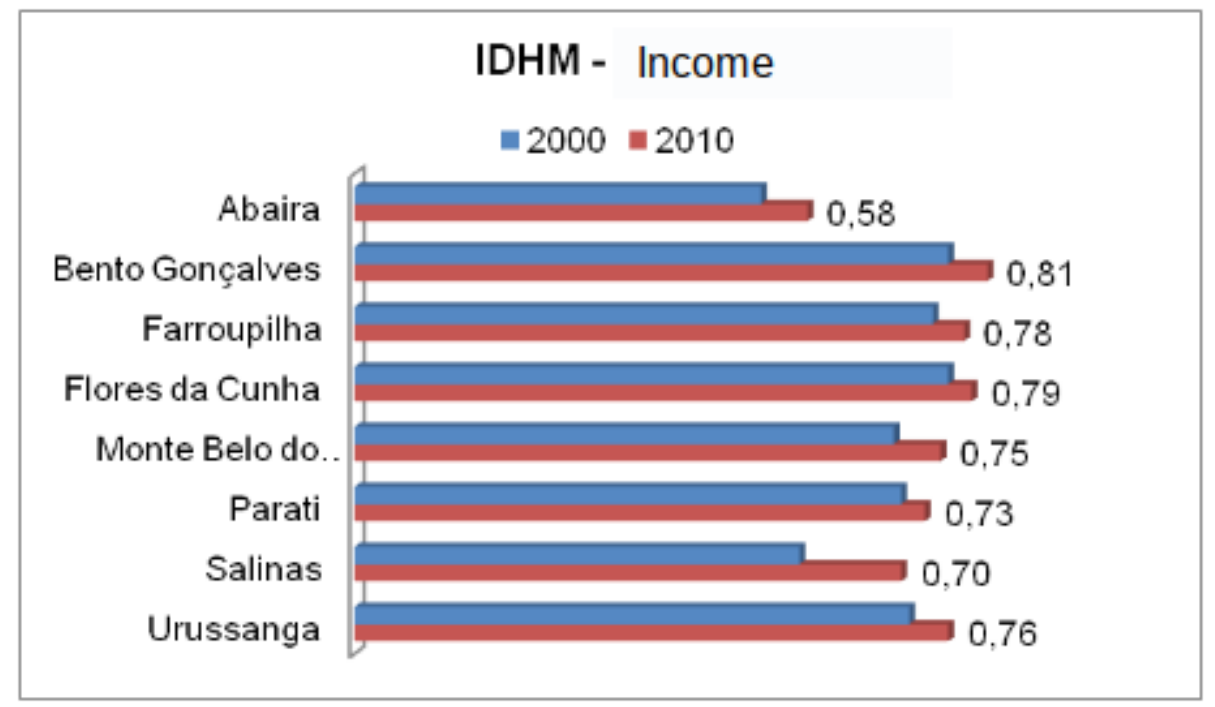

In Figure 4, it is evident that every GIs host town studied in this research had a significant increase in General IDHM, which collaborates for the thesis that the GIs are only installed in areas where already there is a growing development, because the quality of the product and its territory are intertwined (TRIPS, 2018). The counterpoint may be the protection of some product in territories where the development is not as obvious and therefore not ready to manage a certification, causing an inefficiency of that protection. Figure 5 shows the Gini Index of GIs host towns of the alcoholic drinks. It is observed that the cities have highest rates of inequality are Salinas and Parati, having this last town grown enough in this regard in recent years. The towns with the opposing reality are Monte Belo do Sul, which is way ahead of everyone else when it comes to lower levels of inequality. The city of Urussanga coming afterand standing out with good numbers.

Figure 4.Gini Index of the GIs headquarters cities known drinks

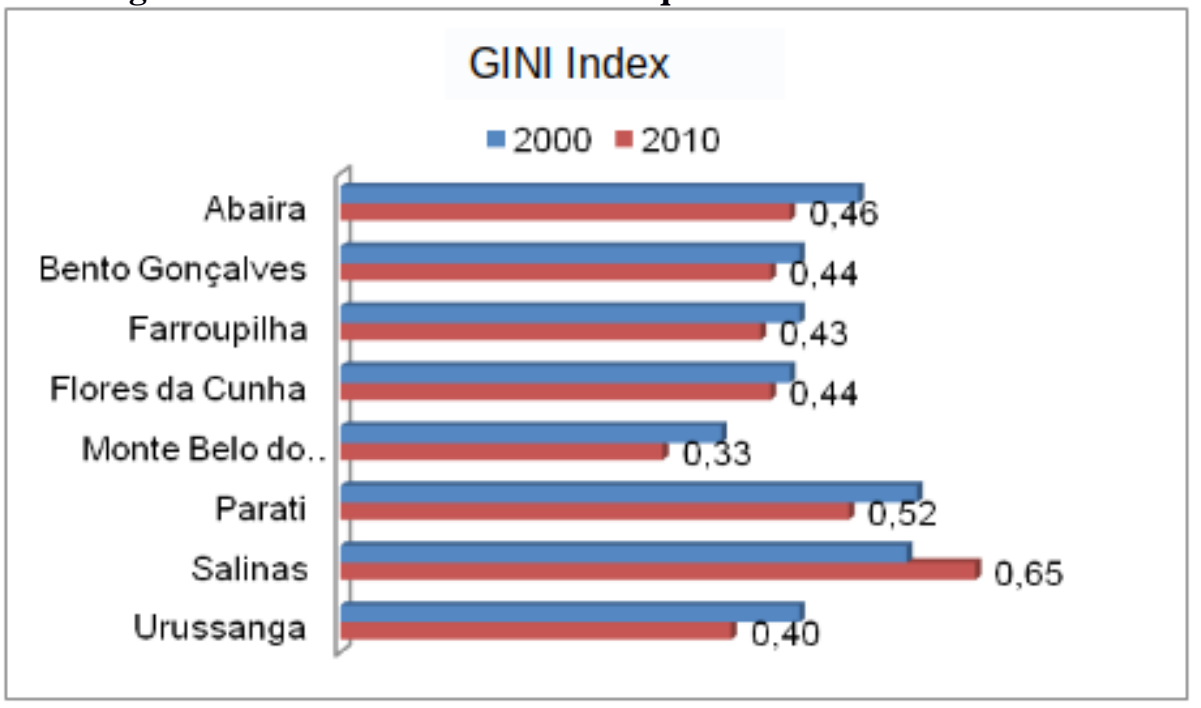


Every GI host town in the Gini index improved, the only exception was the town of Salinas, which worsened their indicators. The counterpoint happens in Figure 3 where is observed an improvement in the income of this town. This means that despite having increased income, the total income distribution of Salinas is uneven, which is a strong trend in the country, because a large portion of the total income is concentrated in the upper classes, while most of the lower classes people are living with very low income (Morgan, 2017).

In the year 2000 as well as 2010, the town of Monte Belo do Sul had the best indicators in the Gini Index. Due to its small territorial extension of $69.598 \mathrm{~km}^{2}$, a population of 2,564 people and a gross domestic product (GDP) per capita of $\mathrm{R} \$ 44,312.72$ (IBGE, 2018), in theory is a town that could be better administered due to its size, and have a better homogeneous distribution income by owning high GDP and a small population. The GI of Monte Belo for sparkling wine was registered in the year 2013, but the region is part of the Vale dos Vinhedos (region with first certificate of Glin Brazil) that owns the certificate since 2002(INPI, 2018). The rich history in the wine sector, and the low level of inequality in the region, support the understanding that the GIs work favorably in the regions with better development and with a history of cultivation of a given product. A fact that represent the degree of importance that the town gives to the wine sector is the area bounded by the GI in relation to the town is $60.22 \%$ (Tonietto et al., 2008). It is observed in table 1 the correlation of Municipal human development indexes in General and in its specificities: education, longevity and income, as well as the Gini Index.

Table 1.Pearson correlation coefficient of the values of $2000-2010$

\begin{tabular}{ll}
\hline Pearson correlation & \\
\hline IDHM & 0,96 \\
GINI & 0,88 \\
IDH - Educação & 0,95 \\
IDHM - Longevidade & 0,85 \\
IDHM - Renda & 0,94 \\
\hline
\end{tabular}

Source: PNUD 2000 to 2010

The Pearson coefficient indicates a connection between two measurements of a variable. Values above 0.85 indicates high correlation and, in this case, the values recorded in 2000 are identical to those registered in 2010, varying in intensity between them. In General, the values of the variables analyzed indicate improvement of development of townsduring these 10 years. Still, the Gini index of the towns of Salinas is the only one who stands out from the normality.

\section{Conclusions}

After analyzing the results, you can infer the following conclusions about the evolution of the GINI index and the towns of IDHMof GI host town of alcoholic drinks, considering its human development:

* Considering the Municipal human development index of income, education and longevity the towns presented higher values and, therefore, have improved the conditions;

* Regarding to Education, the towns that presented the lower values, remained with lower values;

* Regarding the longevity IDHM, the values have become more homogeneous;

* Regarding the Income IDHM, the town of Salinas who had the second lowest value was the town that presented greater evolution;

* Regarding GINI index, the towns presented an index decrease, which is good, with the exception of the town of Salinas who had higher values, which indicates a worsening of the index;

* The profile of the towns is the same after 10 years, but with better values, considering the high correlation found in the results.

In summary, with the exception of Salinas in Income IDHM and GINI Index, the profile of the towns is the same, with higher values. This result may support the theory that the GI has contributed to improving the development of towns in which they are located. This study presents some limitations, because the data are focused on a small group of towns with GI Certificate of alcoholic drinks. The results cannot be assumed and the interpretation is qualitative. As a suggestion for future studies, a field research could aid to a more objective understanding. The increase of the sample of cities with GIs certification would provide more data to understand the reality, as well as compare with other towns of its surroundings that do not have GI in their territories. 


\section{Acknowledgements}

This work would not have been possible without the support of the Postgraduate Program in Intellectual Property of the Federal University of Sergipe and the Foundation for Research and Technological Innovation Support of the State of Sergipe (Fapitec/SE). Special thanks to the LADEC team.

\section{References}

Alves, P. M., Dias, M. T. S., Floresta, S. R., \& Siqueira, M. R. (2017). Proposta e desafios da Política Criminal: um estudo da criminalidade em Iporá-Go (2015-2017). In Anais do Congresso de Ensino, Pesquisa e Extensão da $U E G(C E P E)$.

Biénabe, E., \& Marie-Vivien, D. (2017). Institutionalizing geographical indications in southern countries: lessons learned from Basmati and Rooibos. World Development, 98, 58-67.

Campos, A. C. V., \&Gonçalves, L. H. T. (2018).Aging demographic profile in municipalities in the state of Pará, Brazil.Revista brasileira de enfermagem, 71, 591-598.

Cervo, A. L., Bervian, P. A., \& Silva, R. D. (2007). Metodologia científica. $6^{a}$ edição. São Paulo: Ed. Prentice Hall.

da Costa, F. R., \&Scheffer, M. F. (2017). Avaliação de indicadores sociais no município de Mamborê-PR. Revista Percurso, 9(1), 105-126.

da Cunha, U. A. N., \& Ferreira, L. C. (2016). IDHM dos Estados da região Nordeste do Brasil: Histórico e Análise entre 1991 e 2010. Id onLine Revista de Psicologia, 10(30), 168-181.

Da Silva, E. L., \& Menezes, E. M. (2005). Metodologia da pesquisa e elaboração de dissertação. $4^{\text {a }}$ edição. UFSC, Florianópolis.

da Silva, M. C., Martins, J. D. M., da Silva, J. D. G., \&Araujo, A. O. (2017). Avaliação do desenvolvimento humano da educação das unidades da federação dos anos de 1991, 2000 e 2010 em um único índice. Inter Science Place, 12(4).

Duarte, V. N., \& Cavalcanti, K. A. (2016). Produto Interno Bruto (PIB) versus Índice de Desenvolvimento Humano Municipal (IDHM) na Microrregião de Dourados/MS. DRd-Desenvolvimento Regional em debate, 6(1), 120135.

Gomes, F. B. F., Lana, F. C. F., Oliveira, R. C. D., \& Rodrigues, R. N. (2017). Indicadores da hanseníase no Estado de Minas Gerais e sua relação com o índice de desenvolvimento humano municipal e a cobertura da Estratégia da Saúde da Família. REME rev. min. enferm, 21.

IBGE (2018). Monte Belo do Sul. Retrieved in: <cidades.ibge.gov.br/brasil/rs/monte-belo-do-sul/panorama>. Access:September 10, 2018.

INPI, Pedidos de indicação geográfica concedidos e em andamento, 2018. Retrieved in: <http://www.inpi.gov.br/menu-servicos/indicacao-geografica/pedidos-de-indicacao-geografica-nobrasil>.Access: September 06, 2018.

Joshi, B. K.,Acharya, A. K., Gauchan, D., Singh, D., Ghimire, K. H., \&Sthapit, B. R. (2017). Geographical indication: A tool for supporting on-farm conservation of crop landraces and for rural development.Conference: Conservation and Utilization of Agricultural Plant Genetic Resources in Nepal (BK Joshi, HB KC and AK Acharya, eds). Proceedings of 2nd National Workshop, 22-23 May 2017, Dhulikhel; NAGRC, FDD, DoA and MoAD; Kathmandu, Nepal; pp.50-62

Malta, D. C., Leal, M. D. C., Costa, M. F. L., \& Morais Neto, O. L. D. (2008). Inquéritos Nacionais de Saúde: experiência acumulada e proposta para o inquérito de saúde brasileiro. Revista Brasileira de Epidemiologia, 11, 159-167.

Marconi, M. D. A., \&Lakatos, E. M. (2017). Fundamentos de metodologia científica. 8. ed.-São Paulo: Atlas.

Masullo, Y. A. G., \& Lopes, J. A. V. (2016). Os desafios dagestãointerfederativa frente aos indicadores sociais da região metropolitana da grande São Luís. Revista Tamoios, 12(1).

Medeiros, M. (2012). Medidas de desigualdade e pobreza. Editora Universidade de Brasília: Brasília.

Mendes, C. C. (2017). Evolução fiscal e financeira dos estados brasileiros (2012-2015): desafios conjunturais e restrições estruturais.Boletim regional, urbano e ambiental, IPEA, 17(1).

Morgan, M. (2017). Income Inequality, Growth and Elite Taxation in Brazil: New Evidence Combining Survey and Fiscal Data, 2001-2015. IPC-IG Working Paper. Brasília: International Policy Centre for Inclusive Growth (forthcoming).

Oliveira, F. M., \& Costa, S. M. A. L. (2014). Agricultura familiar no APL/cachaça da região de Salinas: caso de sucesso da cachaça Terra de Ouro. VI Simpósio Reforma Agrária e Questão Rurais NUPEDOR, 1-25. 
Oliveira, M. S., Rech, I. J.,\& Cunha, M. F. (2015). Relação Entre a Distribuição de Riqueza Apresentada na DVA e o IDH-M dos Municípios Sede de Empresas Abertas. In XV Congresso USP Controladoria e Contabilidade, São Paulo, SP, Brasil (Vol. 29).

Pegorare, A. B., De Oliveira, M. Â. C., \& Silva, T. B. (2016). Influência das Commodities Agropecuárias nos Crescimento e na Correlação dos Indicadores Socioeconômicos e Demográficos nos Municípios de Mato Grosso do Sul entre 2000 a 2010.Espacios, 37(14).

Pinto, C. V. D. S., Rocha, B. N., \&Pirani, N. D. C. (2018). Indicadores sociais e desenvolvimento rural: um estudo sobre o índice de desenvolvimento humano municipal rural no Brasil. Boletim regional, urbano e ambiental IPEA. 18,98-105.

Pires, A. R., da Silva, M. C., de Souza, F. J. V., \& da Silva, J. D. G. (2015). Gastos Públicos na Melhoria da Qualidade de Vida: Avaliação de Funções de Governo dos 40 Municípios Melhores Classificados no IDHM. Revista de Administração e Contabilidade da FAT, 7(2), 5-21.

PNUD, Programa das Nações Unidas para o Desenvolvimento. (2010). Série histórica IDH e indicadores selecionados - PNUD. Retrieved in: <http://renastonline.ensp.fiocruz.br/serie-historica-idh-indicadores-selecionadospnud>.Access: July 17, 2018.

Rodrigues, L. S. (2018). Challenges of socioeconomic development in Brazil: inequality and concentration of income in the municipal sphere in the State of São Paulo. Brazilian Journal of Development, 4(5), 2008-2024.

Santos, D. B., Garcia, M. G., \& Della Barba, P. C. D. S. (2017). Qualidade de vida das pessoas com deficiência: revisão sistemática no âmbito de trabalhos brasileiros publicados em bases de dados. Revista Brasileira de Qualidade de Vida, 9(1), 45-62.

Sartori, P. M. \& Silva, I.A. (2016). Análise do Índice de Gini da Cidade de Caxias do Sul Em Comparação ao Estado e País. In Congresso de Pesquisa e Extensão da Faculdade da Serra Gaúcha (ISSN 2318-8014), (Vol. 4).

Siqueira, L. G., Franco, M. A. M., \& Moreira, L. M. (2016). Trilha da Vida em Salinas: uma Ferramenta Lúdica no Ensino de Ciências e na Construção de Conceitos Científicos ligados à Produção Agrícola Local.Experiêcias em Esino de Ciências, 11(1), 88-100.

Tonietto, J., Guerra, C. C., Mandelli, F., da Silva, G. A., de Mello, L. M. R., Zanus, M. C., \& Weber, E. (2008). Monte Belo: características da identidade regional para uma indicação geográfica de vinhos. Bento Gonçalves: EmbrapaUva e Vinho (Circular Técnica 76).

TRIPS (2018).Standards concerning the availability, scope and use of Intellectual Property Rights: Protection of Geographical Indications. Retrieved in:<wto.org/english/docs_e/legal_e/27-trips_04b_e.htm>Access: September 10, 2018.

Wolffenbüttel, A. (2004). O que é? - Índice de Gini. IPEA. Retrieved in: $<$ http://www.ipea.gov.br/desafios/index.php?option=com_content\&id=2048:catid=28\&Itemid=23>.Access: July12, 2018. 